\title{
Tumpang-Tindih Pengaturan Bentuk Tiga Dimensi Dalam Undang-Undang Merek Dan Undang-Undang Desain Industri
}

\author{
Natalia Arinasari Nadeak dan Indirani Wauran \\ Fakultas Hukum Universitas Kristen Satya Wacana \\ Jl. Diponegoro No. 52-60 Salatiga \\ indirani.wauran@uksw.edu;
}

Received: 17 September 2018; Accepted: 14 Januari 2019; Published: 24 April 2019

DOI: 10.20885/iustum.vol26.iss1.art2

\begin{abstract}
This research includes first, to study juridical understanding related to the concept of "three-dimensional form" found in industrial brand and design; second, to analyze whether the three-dimensional form in the industrial brand and design overlapped; and third, to provide prescription for the three-dimensional overlapping arrangement. This research is a normative legal research using a legislative approach, a case approach, and a conceptual approach. From the results of this research, it can be concluded that the first, three-dimensional form is potential to get protection in two different IPR regimes, namely brand and industrial design. Second, these conditions then lead to overlapping arrangements in the brand regime and industrial design regime. Although both brand and industrial design protect the three-dimensional form, the object of protection is different. This is due to the basis of the protection of each regime (the brand emphasizes differentiation, while industrial design emphasizes the new aesthetic impression). Third, the condition is given a suggestion to provide a boundary between the three-dimensional brand and industrial design, as seen from several aspects: general forms, forms that should not be listed, public perception, distinctiveness due to use and expansion of the rejection space for the signs to be made as a brand.
\end{abstract}

Keywords: Brand; industrial design; three-dimensional form; three-dimensional brand

Abstrak

Penelitian ini mencakup pertama, mengkaji pemahaman yuridis terkait konsep "bentuk tiga dimensi" yang dijumpai dalam merek dan desain industri; kedua, menganalisis apakah bentuk tiga dimensi dalam merek dan desain industri mengalami tumpang-tindih; ketiga, memberikan preskripsi atas terjadinya tumpang-tindih pengaturan bentuk tiga dimensi. Penelitian ini merupakan penelitian hukum normatif yang menggunakan pendekatan perundang-undangan, pendekatan kasus, dan pendekatan konseptual. Hasil penelitian ini menyimpulkan bahwa pertama, bentuk tiga dimensi berpotensi mendapatkan perlindungan pada dua rezim HKI yang berbeda, yaitu merek dan desain industri. Kedua, kondisi tersebut menimbulkan tumpang-tindih pengaturan dalam rezim merek dan rezim desain industri. Meskipun merek dan desain industri sama-sama melindungi bentuk tiga dimensi, namun objek perlindungannya berbeda. Hal ini disebabkan oleh dasar yang menjadi landasan perlindungan masingmasing rejim (merek menekankan pada daya pembeda, sementara desain industri menekankan pada kesan estetis yang baru). Ketiga, atas kondisi tersebut diberikan saran untuk memberikan batasan antara merek tiga dimensi dan desain industri, yang dilihat dari beberapa aspek yaitu bentuk umum, bentuk yang tidak boleh di daftarkan, persepsi publik, kekhasan akibat penggunaan dan perluasasn ruang cakupan penolakan suatu tanda untuk dapat dijadikan merek.

Kata-kunci: Merek; desain industri; bentuk tiga dimensi; merek tiga dimensi 


\section{Pendahuluan}

Intellectual Property Right (IPR) diartikan sebagai hak atas kekayaan yang timbul karena kemampuan intelektual m ‘anusia. ${ }^{1}$ Hak Kekayaan Intelektual (HKI) selalu dikaitkan dengan tiga elemen, yaitu, adanya sebuah hak ekslusif yang diberikan oleh hukum, hak tersebut berkaitan dengan usaha manusia yang didasarkan pada kemampuan intelektual dan kemampuan intelektual tersebut memiliki nilai ekonomi. ${ }^{2}$ HKI merupakan cara melindungi kekayaan intelektual dengan menggunakan instrumen-instrumen hukum yang meliputi Hak Cipta, Paten, Merek dan Indikasi Geografis, Rahasia Dagang, Desain Industri, Desain Tata Letak Sirkuit Terpadu, dan Perlindungan Varietas Tanaman. ${ }^{3}$ Perlindungan HKI diletakkan pada pemikiran bahwa atas kreativitas seharusnya dianugerahi hak eksklusif sebagai imbalan atas jerih payahnya, sehingga dalam hal ini berlaku prinsip "siapa yang menabur, berhak untuk menuai" 4 atau no free riding. Di samping itu, tujuan utama sistem hukum HKI adalah menjamin agar proses kreatif tersebut terus berlangsung dengan menyediakan perlindungan hukum yang memadai dan menyediakan sanksi terhadap pihak yang menggunakan proses kreatif tersebut tanpa izin. ${ }^{5}$

Perlu ada kejelasan pengaturan di bidang HKI untuk menjamin terpenuhinya hak tersebut, salah satunya mengenai merek tiga dimensi. Merek menurut Pasal 1 Angka 1 Undang-Undang Republik Indonesia Nomor 20 Tahun 2016 tentang Merek dan Indikasi Geografis (UU Merek) adalah:

Merek adalah tanda yang dapat ditampilkan secara grafis berupa gambar, logo, nama, kata, huruf, angka, susunan warna, dalam bentuk 2 (dua) dimensi dan/atau 3 (tiga) dimensi, suara, hologram, atau kombinasi dari 2 (dua) atau lebih unsur tersebut untuk membedakan barang dan/atau jasa yang

${ }^{1}$ Affilyonna Purba, Gazalba Saleh dan Adriana Krisnawati, Konsep Hak Kekayaan Intelektual, Penerbit Rineka Cipta, Jakarta, 2005, hlm. 12. Bandingkan juga dengan Achmad Zen Umar Purba, Hak Kekayaan Intelectual Pasca TRIPs, Alumni, Bandung, 2005, hlm. vii. Lihat pula pengertian oleh Ditjen HKI (Bekerja sama dengan EC-ASEAN IPRs Co-operation Programme (ECAP II), Buku Panduan Hak Kekayaan Intelektual Dilengkapi dengan Peraturan Perundang-Undangan Di Bidang Hak Kekayaan Intelektual, Jakarta, ditjen HKI-ECAP II, 2006, hlm. 7 2.

2 Tomy Suryo Utomo, Hak Kekayaan Intelektual (HKI) di Era Global, Graha Ilmu, Yogyakarta, 2010, hlm.

${ }^{3}$ Mastur, "Perlindungan Hukum Hak Kekayaan Intelektual Dibidang Paten", Jurnal Ilmiah Ilmu Hukum QISTI Vol. 6 No. 1 Januari 2012, hlm. 67. hlm. 1

${ }^{4}$ Indirani Wauran-Wicaksono, Pengantar Hukum Kekayaan Intelektual, Penerbit Tisara Grafika, Salatiga, 2017,

${ }^{5}$ Sufiarina, "Hak Prioritas Dan Hak Ekslusif Dalam Perlindungan HKI", Jurnal Hukum ADIL Vol. 3 No. 2, hlm. 269. 
diproduksi oleh orang atau badan hukum dalam kegiatan perdagangan barang dan/atau jasa.

Berdasarkan penjelasan di atas, dapat dilihat bahwa Undang-Undang Merek dan Indikasi Geografis menambahkan cakupan perlindungan merek untuk suara, tiga dimensi dan hologram. Artikel ini akan membahas satu diantaranya, yaitu bentuk tiga dimensi. Bentuk tiga dimensi yang dimaksudkan di sini adalah tanda yang memiliki tinggi, lebar dan kedalaman. ${ }^{6}$

Sebelum UU Merek terbaru ini disahkan, telah berlaku Undang-Undang No. 31 Tahun 2000 tentang Desain Industri (UU Desain Industri) yang mengatur mengenai perlindungan terhadap bentuk tiga dimensi yang dapat digunakan untuk menghasilkan suatu produk, barang, komoditas industri, atau kerajinan tangan. ${ }^{7}$ Perkembangan ini mengindikasikan kesulitan membedakan perlindungan merek dan desain industri ${ }^{8}$ karena telah terjadi tumpang-tindih pengaturan.

Bentuk tiga dimensi merupakan obyek yang masuk ke dalam ruang lingkup pengaturan dua UU, yaitu UU Merek dan juga UU Desain Industri. Di sinilah terjadi tumpang-tindih pengaturan antara UU Merek dan UU Desain Industri. Pemahaman mengenai bentuk tiga dimensi yang termasuk dalam merek dan tiga dimensi menjadi hal yang penting untuk mencegah terjadinya tumpang-tindih pengaturan bentuk tiga dimensi. Kesalahan dalam pemahaman mengenai bentuk tiga dimensi dapat mengakibatkan kekeliruan dalam memberikan atau tidak memberikan perlindungan di bidang HKI terhadap bentuk tiga dimensi. Oleh karenanya, artikel ini tentu saja lebih dari sekedar menuliskan pengertian yang tertulis dalam Undang-undang, akan tetapi memberikan justifikasi perlindungan bentuk tiga dimensi dalam masing-masing bidang (sebagaimana akan diuraikan pada bagian pertama). Selanjutnya, pada bagian kedua akan dipaparkan persinggungan antara bentuk tiga dimensi dalam merek dan desain industri sehingga diperoleh pemahaman mengenai aspek-aspek persamaan dan perbedaan dalam merek dan desain industri. Dengan sudut pandang demikian, pemikiran

6 Sandra Edelman, et.al., "Annual Review: The Twelfth Annual International Review of Trademark Jurisprudence", Official Journal of The International Trademark. Association, Volume 95, Nomor 2, 2005, hlm. 342.

7 Pasal 1 angka 1 Undang-Undang No 31 Tahun 2000 tentang Desain Industri

8 OK Saidin, Aspek. Hukum Hak Kekayaan Intelektual, PT Raja Grafindo, Jakarta, 2013, hlm. 347. 
dalam artikel ini memiliki urgensi untuk dilakukan, tanpa 'menunggu' terjadinya kasus yang nyata, bahkan dapat menjadi pedoman bagi pemeriksa merek dan desain industri serta hakim dan pihak lain yang membutuhkan. ${ }^{9}$

\section{Rumusan Masalah}

Berdasarkan pada uraian di atas, maka dirumuskan masalah sebagai berikut: pertama, apakah yang menjadi pemahaman yuridis terkait dengan konsep "bentuk tiga dimensi" yang dijumpai dalam merek dan desain industri? Kedua, apakah terdapat tumpang-tindih bentuk tiga dimensi dalam merek dan desain industri? Ketiga, apakah yang menjadi preskripsi atas tumpang-tindih pengaturan merek tiga dimensi?

\section{Tujuan Penelitian}

Adapun tujuan dari penelitian ini adalah: pertama, memberikan pemahaman yang menyeluruh melalui analisis mengenai konsep "bentuk tiga dimensi" yang dijumpai dalam merek dan desain industri; sehingga diperoleh pemahaman mengenai bagaimana seharusnya memaknai bentuk tiga dimensi dalam merek dan desain industri. Kedua, menganalisis dan menjelaskan tumpang-tindih antara bentuk tiga dimensi dalam merek dan desain industri. Ketiga, memberikan preskripsi atas tumpang-tindih pengaturan bentuk tiga dimensi tersebut.

\section{Metode Penelitian}

Penelitian ini merupakan penelitian hukum (legal research), oleh karenanya dengan sendirinya penelitian ini merupakan penelitian normatif karena melandaskan pada nilai/norma. Penelitian yang demikian dapat pula disebut sebagai doctrinal research, karena penelitian ini: "identify, analyse and synthesise the content of the law."10 Adapun bahan hukum hukum (legal materials atau authorities) yang digunakan dalam penelitian ini terdiri dari bahan hukum primer, sekunder, dan tertier (primary authority, secondary authority dan tertiary authority) terkait dengan bentuk tiga dimensi dalam merek dan desain industri. Adapun pendekatan

\footnotetext{
${ }^{9}$ Lihat kasus Tripp Trapp Case C-205/13 Hauck GmbH \& Co. KG v Stokke A/S, Stokke Nederland BV, Peter Opsvik and Peter Opsvik $A / S$. Kasus ini merupakan perselisihan antara bentuk tiga dimensi yang sudah didaftarkan dalam desain industri kemudian didaftarkan lagi dalam merek.

10 Terry Hutchinson, "Doctrinal Research: Researching the Jury" dalam Dawn Watkins \& Mandy Burton (eds.), Research Methods in Law (Routledge 2013), hlm. 9.
} 
yang digunakan adalah pendekatan perundang-undangan, pendekatan kasus (dengan melakukan telaah terhadap kasus-kasus terkait bentuk tiga dimensi); dan juga pendekatan konseptual (dilakukan dengan melakukan telaah tentang pandangan-pandangan terkait isu hukum yang dihadapi guna melahirkan pengertian yang relevan terkait dengan bentuk tiga dimensi dalam merek dan desain industri).

Pengumpulan bahan-bahan hukum dalam penelitian ini terutama mengandalkan pada dukungan literatur (library-based research). ${ }^{11}$ Bahan hukum yang digunakan adalah bahan hukum primer yaitu Undang-undang Republik Indonesia Nomor 20 Tahun 2016 tentang Merek dan Indikasi Geografis dan Undang-undang Republik Indonesia Nomor 31 Tahun 2000 tentang Desain Industri tersebut bahan hukum sekunder yaitu buku, jurnal dan literatur pendukung. Bahan-bahan hukum tersebut kemudian disistematisasi, untuk kemudian dilakukan analisis dengan memanfaatkan metode interpretasi atau penafsiran, terutama metode penafsiran sistematis dan penafsirat gramatikal.

\section{Hasil Penelitian dan Pembahasan}

\section{Bentuk Tiga Dimensi dalam Merek dan Desain Industri}

Merek adalah tanda yang memiliki daya pembeda dan digunakan dalam kegiatan perdagangan barang dan/atau jasa. Merek tiga dimensi merupakan perlindungan kekayaan intelektual berupa merek yang diberikan pada sebuah tanda dengan konfigurasi bentuk tiga dimensi. Merek tiga dimensi diartikan sebagai tanda yang menempati tiga dimensi ruang yakni tinggi, lebar, dan kedalaman. Istilah tanda tiga dimensi mengacu pada bentuk atau lekuk suatu produk dan bahkan juga mengacu pada bentuk kemasan produk itu sendiri. ${ }^{12}$

Pengertian mengenai bentuk tiga dimensi tidak dijelaskan lebih lanjut di dalam UU Merek. Tetapi, ada pemahaman merek tiga dimensi yang dikemukakan

\footnotetext{
11 Oleh karena itu, sebagai standar universal untuk law school di seluruh dunia, law library diposisikan sebagai laboratoriumnya untuk orang hukum (lanyer's labaratory). Misalnya Standar 5.1. The Council of Australian Law Deans Standards for Australian Law Schools yang menyatakan: "Recognising that the law library has a distinctive role in the university, and is appropriately described, to underline the parallel with the essential equipment of the scientist, as 'the lawyer's laboratory."."

12 Ana Wahyu, Konsep Merek Tiga Dimensi dalam Hukum Merek Indonesia, Skripsi Fakultas Hukum Universitas Kristen Satya Wacana, Salatiga, 2018, hlm. 45.
} 
oleh praktisi HKI di Indonesia yang berpendapat bahwa merek tiga dimensi memiliki ciri khas tersendiri dimana beliau memberi contoh terhadap produk Coca-Cola yang sudah memiliki reputasi dan nama di mata konsumen. Beliau berpendapat bahwa: 13

Kekhasan dari bentuk tiga dimensi tersebut dapat terlihat apabila dalam ruangan gelap seorang konsumen dapat mengidentifikasi produsen suatu produk hanya dengan memegang botol tersebut, hal ini dikarenakan botol tersebut memang memiliki ciri khas yang membuat konsumen hanya dengan memegang botol tersebut sudah dapat mengidentifikasi produsen produk tersebut. Fungsi sebagai tanda pengenal dalam hal ini sejalan dengan fungsi dari sebuah merek, di sinilah salah satu cara melihat kekhasan dari suatu tanda tiga dimensi dalam fungsinya sebagai sebuah merek.

Pendapat ini hanya dapat berlaku terhadap bentuk tiga dimensi yang telah digunakan dalam jangka waktu tertentu dimana telah memiliki reputasi atau dapat dikatakan telah memiliki makna sekunder (secondary meaning). Makna sekunder (secondary meaning) merupakan istilah umum dalam common law dimana suatu bentuk tiga dimensi dianggap telah memiliki fungsi lain. Tanda tiga dimensi tidak hanya bersifat fungsional, melainkan tanda tersebut juga telah menjadi pengenal dan merupakan suatu pembeda di mata produk. ${ }^{14}$ Namun cara ini hanya dapat dilakukan terhadap bentuk tiga dimensi yang telah memiliki secondary meaning dan tidak aplikatif terhadap sebuah pemeriksaan bentuk tiga dimensi yang belum memiliki secondary meaning. Tentu saja hal ini akan menutup kemungkinan pendaftaran bentuk tiga dimensi yang masih baru atau belum memiliki reputasi sebagai merek.

Sebuah tanda dari bentuk tiga dimensi dapat dilindungi dengan hak merek bila memenuhi syarat mutlak berupa adanya daya pembeda (distinctive character). Maksudnya, tanda bentuk tiga dimensi yang dipakai tersebut mampu untuk membedakan barang atau jasa sejenis yang diproduksi suatu perusahaan dari perusahaan lainnya. Apabila merek sebagai suatu tanda tidak memiliki daya pembeda, maka tanda itu tidak dapat dijadikan sebagai suatu merek. ${ }^{15}$ Konsep

\footnotetext{
${ }^{13}$ Gatot Supramono, Op. Cit., hlm. 60

${ }^{14}$ Bagus Satrio Lestanto, Konsep Perlindungan Merek Tiga Dimensi: Definisi, Perlindungan dan Penerapan Hukum, Skripsi, Universitas Indonesia, Jakarta, hlm. 60

${ }^{15}$ Fajar Nurcahya Dwi Putra, "Perlindungan Hukum Bagi Pemegang Hak Atas Merek Terhadap Perbuatan Pelanggaran Merek", Jurnal Ilmu Hukum Edisi: Januari - Juni 2014, hlm. 98.
} 
daya pembeda memiliki fungsi yang sifatnya vital dan fundamental dalam suatu merek. ${ }^{16}$ Keberadaan daya pembeda pada suatu merek akan berdampak pada kemampuan merek tersebut agar tidak menyebabkan kebingungan pada saat merek tersebut dipasarkan. Di dalam UU Merek tidak disebutkan secara eksplisit apa yang dimaksud dengan daya pembeda.

Pasal 21 angka 1 UU Merek dapat dipahami bahwa penentuan daya pembeda dilihat dari apakah tanda tersebut mempunyai persamaan pada pokoknya atau keseluruhannya dengan merek terkenal atau dengan merek yang sudah terlebih dahulu terdaftar. Dikatakan adanya bukti persamaan pada pokoknya apabila tanda tersebut memiliki kemiripan yang disebabkan oleh adanya unsur yang dominan antara tanda yang satu dengan tanda yang lain. Hal ini menimbulkan kesan adanya persamaan, baik mengenai bentuk, cara penempatan, cara penulisan atau kombinasi antara unsur, maupun persamaan bunyi ucapan yang terdapat dalam merek tersebut. Selain itu dikatakan dalam sebuah tanda tidak memiliki daya pembeda apabila tanda tersebut terlalu sederhana, umum ataupun tanda tersebut terlalu rumit.

Penerapannya, seringkali untuk menentukan daya pembeda hanya diperhatikan apakah merek tersebut memiliki persamaan dengan merek lain yang telah terdaftar. Tentu pedoman yang seperti ini tidak dapat diterapkan untuk merek tiga dimensi. Sebagai contoh para pemeriksa merek ${ }^{17}$ menyatakan bahwa sebuah merek berhak mendapatkan hak merek atas bentuk tiga dimensi sematamata karena belum ada bentuk yang sama yang telah terdaftar sebagai merek. Sebagai contoh, sebuah bentuk terdaftar dengan nomor IDM000530607 untuk jenis barang minuman yang tidak beralkohol, minuman buah, jus buah dan sari buahbuahan. ${ }^{18}$ Pada pemeriksaan substantif, penerapan daya pembeda pada bentuk tersebut hanya berdasarkan tidak ditemukannya persamaan pada pokoknya

\footnotetext{
16 Wauran dan Kurnia, “Confusion dan Pembatalan Merek oleh Pengadilan”, Mimbar Hukum Vol. 27, Yogyakarta, 2015, hlm. 276.

${ }^{17}$ Berdasarkan Peraturan Menteri Hukum dan Hak Asasi Manusia Republik Indonesia No 37 Tahun 2017 tentang Tata Cara Penyesuaian/ Inpassing, Pelaksanaan Uji Kompetensi dan Penetepan Kebutuhan dalam Rangka Penyesuaian/ Inpassing Jabatan Fungsional Merek, dalam Pasal 3 dan Pasal 4 dikatakan pihak yang berwenang serta bertanggung jawab dalam pemeriksaan merek adalah Jabatan Fungsional Pemeriksa Merek dan Pemeriksa Merek.

${ }^{18} \mathrm{Ibid}$.
} 
dengan merek yang telah terdaftar. Padahal bentuk tersebut banyak digunakan oleh produk lain yang di contohkan dibawah ini:

Bentuk Kemasan Makanan Dan Minuman ${ }^{19}$
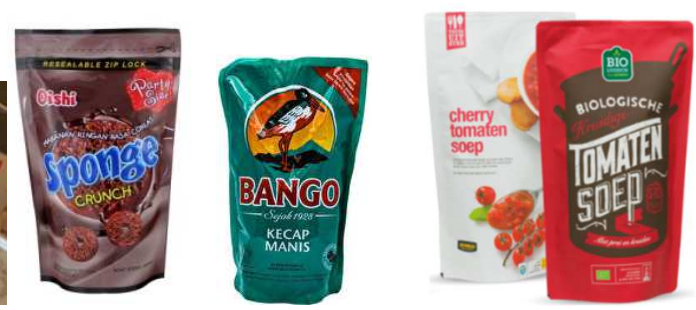

UU Merek secara implisit mengatur bahwa bentuk tiga dimensi dapat didaftarkan sebagai merek apabila memiliki daya pembeda. Selain itu, bentuk tiga dimensi juga harus dapat direpresentasikan baik secara gambar dan/atau grafis. Syarat lainnya adalah permohonan pendaftaran bentuk tiga dimensi harus di ajukan dengan itikad baik. Pemohon dengan itikad tidak baik akan ditolak pendaftarannya. ${ }^{20}$ Syarat permohonan pendaftaran bentuk tiga dimensi sebagai merek juga diatur pada Pasal 21 dan Pasal 22 UU Merek.

Desain industri, di sisi lain mempunyai konsep tersendiri terkait dengan bentuk tiga dimensi. Desain adalah bentuk karya seseorang hasil curahan kemampuan intelektualnya, yang terwujud tidak hanya dalam bentuk karya di atas kertas saja, melainkan sudah terbentuk dalam wujud nyata suatu benda yang memiliki nilai manfaat bagi kehidupan manusia. ${ }^{21}$ Bentuk tersebut dikatakan tiga dimensi karena dapat terlihat dari segala sisi dan bentuk tersebut memiliki volume. Bentuk tiga dimensi dapat dilindungi dengan hak desain industri.

Desain industri memberikan perlindungan terhadap bentuk dua dimensi dan tiga dimensi, namun yang akan dibahas dalam tulisan ini hanya bentuk tiga dimensi. Esensi objek pengaturan perlindungan hukum di bidang desain yaitu karya-karya berupa produk yang pada dasarnya merupakan "pola (pattern)" yang digunakan untuk membuat/memproduksi barang secara berulang. ${ }^{22}$ Dari pemahaman ini, desain industri menitikberatkan perlindungannya terhadap

\footnotetext{
${ }^{19}$ Kemasan Makanan dan Minuman dikenal dengan sebutan kemasan doypack, sumber google https://www.google.com/search?q=kemasan, dikunjungi pada 17 Mei 2018.

20 Indirani Wauran-Wicaksono, Op. Cit., hlm. 16.

${ }^{21}$ Muhammad Djumhamna, Aspek - Aspek Hukum Desain Industri di Indonesia, Citra Aditya Bakti, Bandung, 1999, hlm. 1.

${ }^{22}$ Muhammad Djumhamna, Ibid., hlm. 41.
} 
bentuk, yang mana bentuk tesebut dipahami dalam desain industri adalah penampilan luar (physical appearance) yang memberikan kesan estetis. ${ }^{23}$

Menurut Kamus Besar Bahasa Indonesia, estetis didefinisikan sebagai nilai terhadap keindahan. ${ }^{24}$ Estetis atau keindahan adalah suatu kondisi yang berkaitan dengan sensasi keindahan yang dirasakan seseorang, tetapi rasa keindahan tersebut akan dirasakan apabila adanya perpaduan yang harmonis dari elemenelemen keindahan yang terkandung pada suatu objek. ${ }^{25}$ Aspek nilai estetis pada penampilan suatu produk mengacu pada nilai visual dari desain yang dilandasi pertimbangan seperti bentuk keseluruhan, unsur penampilan, pembuatan detil, proporsi, tekstur, warna, grafis dan penyelesaian akhir yang memberikan nilai keindahan. ${ }^{26}$ Faktor keindahan memiliki nilai-nilai ekstrinsik dan intrinsik, dimana nilai ekstrinsik erat hubungannya dengan bentuk luar (kesan), sedangkan nilai intrinsik erat hubungannya dengan pesan atau makna yang terkandung di dalamnya. ${ }^{27}$ Bentuk luar tersebut dipahami sebagai bentuk dalam pola tiga dimensi. Bentuk tiga dimensi yang memiliki bentuk estetis dalam desain industri berfungsi untuk menarik konsumen membeli produk tersebut. Dengan kata lain, nilai estetis berfungsi untuk menambah nilai komersil dari bentuk tersebut. ${ }^{28}$ Kesan estetis yang dimaksud disini dapat ditentukan dengan penampilan atau bentuk terluar dari suatu kreasi yang dapat dilihat secara kasat mata. ${ }^{29}$

Kesan Estetis pada Desain Indsutri30

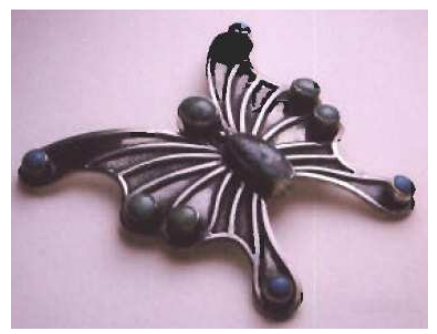

Kesan Estetis pada Desain Indsutri30
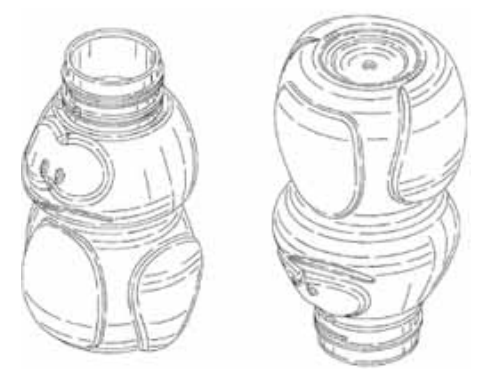

${ }^{23}$ Ibid.

${ }^{24}$ Kamus Besar Bahasa Indonesia, https://kbbi.web.id/estetis, di kunjungi pada 10 Mei 2018.

25 Artini Kusmiati, Dimensi Estetika Pada Karya Arsitektur dan Desain, Djambatan, Jakarta, 2004, hlm. 5

${ }^{26}$ Selain itu, sub bidang yang lebih khusus seperti desain produk, yang meliputi furniture, perlengkapan rumah tangga, alat-alat elektronik dan lain-lain. Jhon Heskett, Desain Industri, terjemahan Chandra Johan, Rajawali, Jakarta, 1968, hlm. 5.

${ }^{27}$ Ibid.

${ }^{28}$ Badan Pembinaan Hukum Nasional, Ibid. hlm.128.

${ }^{29}$ Dewi Susiana, "Pembatalan Desain Industri Karena Alasan Mempunyai Persamaan Pada Pokoknya", PREMISE LAW JURNAL Vol 1 No 2, Medan, 2013, hlm. 5.

${ }^{30}$ Direktorat jenderal kekayaan intelektual, pangkalan data kekayaan intelektual desain indsutri, gambar pertama " bros bentuk kupu-kupu" dengan nomor pendaftaran idd000032807 dan gambar kedua "botol dengan bentuk katak" dengan nomor pendaftaran idd000039919 yang terdaftar dibawah perlindungan desain industri, 
Definisi dan ruang lingkup dari bentuk yang memiliki nilai estetis tidak ditemukan di dalam UU Desain Industri. Hal ini menyebabkan banyak terjadinya kerancuan terhadap penilaian estetis. ${ }^{31}$ Padahal untuk menilai suatu kreasi yang memiliki kesan estetis atau tidak tentu saja bukan hal yang mudah. Penilaian ini bersifat subjektif, baik dari sudut pandang pemeriksa maupun pemilik desain. ${ }^{32}$ Oleh karena itu, perlu dicapai kepastian hukum dalam penentuan kesan estetis tersebut. Hal ini juga diakui sebagai kendala dan kelemahan UU Desain Industri. ${ }^{33}$

Menurut UU Desain Industri, objek perlindungan hukum desain industri adalah desain industri yang baru (novel). Sebagaimana diatur dalam Pasal 2 UU Desain Industri, hak desain industri diberikan untuk bentuk tiga dimensi yang baru. Bentuk tiga dimensi dianggap baru apabila pada tanggal penerimaan, bentuk tersebut tidak sama dengan pengungkapan yang telah ada sebelumnya. Desain tersebut harus asli atau orisinil dan harus memenuhi syarat bahwa suatu objek telah dibuat berdasarkan suatu desain. ${ }^{34}$ Unsur kebaruan suatu bentuk tiga dimensi bukan dilihat dari tidak adanya bentuk tiga dimensi sejenis yang terdaftar, akan tetapi mensyaratkan pada bentuk tiga dimensi yang belum pernah dipergunakan di Indonesia maupun di luar Indonesia. ${ }^{35}$ Maka dari itu, penentuan suatu bentuk tiga dimensi yang baru bukan dilihat dari pendaftaran pertama kali diajukan, akan tetapi harus dilihat ada atau tidaknya pengungkapan atau publikasi sebelumnya baik tertulis maupun tidak tertulis. Pengungkapan terlebih dahulu oleh para desainer akan menghilangkan unsur kebaruan. ${ }^{36}$ Dengan kata lain, UU Desain Industri menekankan unsur kebaruan dapat hilang apabila telah dipublikasikan dengan berbagai macam cara dan di negara manapun. ${ }^{37}$

Dilihat dari pengertian yang diberikan oleh Pasal 2 UU Desain Industri, kebaruan hanya bertitik tolak pada tanggal penerimaan pendaftaran. Desain

https://pdki-indonesia.dgip.go.id/index.php/di?q=bentuk \&type=1\&filter_by=didaftar dikunjungi pada 18 Mei 2018.

${ }^{31}$ Ibid. hlm. 21.

32 Endang Purwaningsih, Perkembangan Hukum Intellectual Property Rights, Ghalia Indonesia, Bogor, 2005,

${ }_{33}$ Badan Pembinaan Hukum Nasional, Naskah Akademik Rancangan Undang-Undang Tentang Desain Industri, Jakarta, 2013, hlm. 3.

34 T. Black, Intellectual Property in Industry, Butterworths, London, 1989, hlm. 163-164.

35 Muhammad Djumhamna, Op. Cit., hlm. 10.

36 Muhammad Djumhamna, Ibid., hlm. 135.

${ }^{37}$ Liona Isna Dewanti, “Tolok Ukur Kebaruan Dalam Desain Industri”, Ius Quia Iustum Law Journal of Islamic University of Indonesia NO. 1 VOL. 14 JANUARI 2007, hlm. 88. 
industri yang didaftarkan tidak sama dengan pengungkapan yang telah ada sebelumya. Ketentuan ini sama sekali belum memberikan sebuah kepastian yang jelas mengenai prinsip kebaruan dari desain tersebut, sehingga dalam prakteknya penafsiran terhadap prinsip kebaruan tersebut diserahkan kepada hakim dalam proses pengadilan jika terjadi sengketa. ${ }^{38}$ Penentuan kebaruan menimbulkan persoalan yang cukup serius. ${ }^{39}$ Berikut kasus yang akan dijelaskan guna membuktikan ketidaktegasan dalam penerapan unsur kebaruan dalam desain industri di Indonesia. Terdapat 2 perkara yang inkonsistensi dalam pertimbangan dan putusannya, yang mana dipimpin oleh ketua majelis hakim yang sama, dan perkaranya mengenai hal yang sama yaitu mengenai pembatalan Desain Industri.

Perkara pertama yang diputus oleh Mahkamah Agung dalam tingkat kasasi dan telah berkekuatan hukum tetap adalah sengketa antara Ferry Sukamto sebagai Penggugat melawan IR. Susianto sebagai Tergugat Kasus tentang Desain Industri Tempat Disk. ${ }^{40}$ Dalam pengajuan gugatan ini, Penggugat mengajukan keberatan atas desain Tergugat yang didaftarkan di Dirjen HAKI dengan nomor IDD000001825.41 Bahwa dalam gugatanya penggugat mendalilkan desain tersebut tidak baru (not novel) karena sebelumnya Tergugat telah memasarkan tempat disk dengan desain yang serupa. ${ }^{42}$ Penggugat telah mempergunakan desain industri tempat disk tersebut sejak tahun 2000, maka beliau menyatakan bahwa desain industri tempat disk itu telah menjadi milik umum (public domain) dan bukan merupakan desain industri yang baru. ${ }^{43}$

38 Agitya Kresna Adiyan, "Penerapan Prinsip Kebaruan (Novelty) Dalam Perlindungan Desain Industri di Indonesia, (Studi Kasus Desain Industri Iphone 3G Apple Inc. v. Galaxy S Samsung Electronics Co.Ltd)”, Jurnal Ilmiah, Fakultas Hukum Universitas Brawijaya, Malang, 2013 hlm. 7.

39 Budi Santoso, Butir-Butir Berserakan tentang Hak. Atas Kekayaan Intelektual (Industri), CV. Mandar Maju, Bandung, 2005, hlm. 9.

${ }^{40}$ Putusan Mahkamah Agung Pada Tingkat Kasasi Dengan Perkara Nomor : 022 K/N/HaKI/2006 dengan susunan Majelis Hakim Perkara, Marianna Sutadi, SH., sebagai ketua majelis, Susanti Adi Nugroho, SH.,MH., dan Prof. DR. Mieke Komar,SH.,MCL., sebagai anggota majelis.

${ }^{41}$ Ibid.

${ }^{42}$ Ibid.

${ }^{43}$ Ibid. 


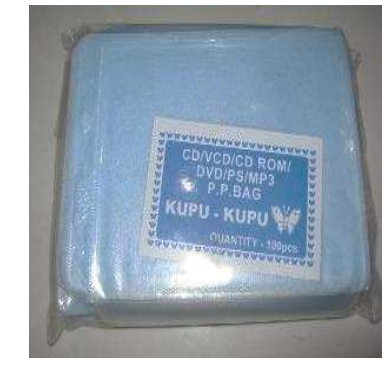

Bentuk di lindungi Desain Industri 44

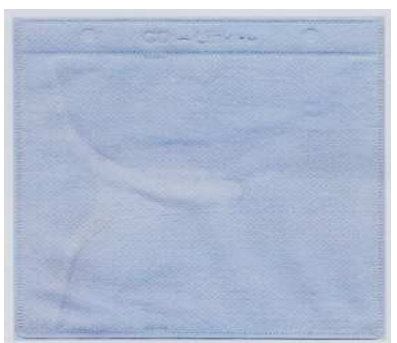

Bentuk yang digunakan oleh umum ${ }^{45}$

Putusan Mahkamah Agung ini berakhir dengan putusan yang mengabulkan kasasi Penggugat dan membatalkan hak Desain Industri Tergugat karena tidak baru. Mahkamah Agung mempertimbangkan bahwa desain industri tempat disk Tergugat yang telah mendapatkan sertifikat hak desain industri adalah tidak baru. Hal ini dibuktikan dengan tidak terdapat perbedaan secara signifikan dengan tempat disk yang diproduksi dan diperdagangkan oleh Penggugat lebih dahulu dari tanggal penerimaan pendaftaran Tergugat. Dalam kasus ini, Pengadilan menafsirkan bahwa desain industri dianggap baru apabila desain tersebut memiliki perbedaan yang jauh dan signifikan dari desain yang telah ada sebelumnya, sehingga tidak ada unsur kemiripan dengan desain yang telah ada terlebih dahulu. ${ }^{46}$

Perkara kedua adalah perkara Desain Industri antara PT. Hitachi Contruction Machinery Indonesia sebagai Penggugat melawan PT. Basuki Pratama Engineering sebagai Tergugat tentang Desain Industri Mesin Boiler yang juga dipimpin oleh ketua hakim yang sama pada perkara yang dijelaskan sebelumnya. ${ }^{47}$ Dalam sengketa ini, Penggugat merupakan pihak yang berkepentingan sebagai produsen mesin-mesin industri termasuk mesin boiler. ${ }^{48}$ Dimana dalam sengketa ini

${ }^{44}$ Direktorat Jenderal Kekayaan Intelektual, Pangkalan Data Kekayaan Intelektual Desain Indsutri, plastik pembungkus CD, VCD dan DVD https://pdkiindonesia.dgip.go.id/index.php/di/Vml0WS93dFM0RIRDVFFBajVqRTBuQT09?q=ID+0002596\&type=1 dikunjungi pada 18 Mei 2018..

45 Putusan Mahkamah Agung perkara Nomor : 022 K/N/HaKI/2006 bukti PGa

${ }^{46}$ Ibid.

${ }^{47}$ Putusan Mahkamah Agung pada tingkat kasasi No.19 K/N/HaKI/2006 dengan susunan Majelis Hakim Perkara yang juga diketuai oleh Marianna Sutadi, SH., Atja Sondjaja, SH., dan DR. Harifin Tumpa, SH., MH., sebagai anggota majelis.

${ }^{48}$ Ibid. 
penggugat mendapati adanya sertifikat desain industri mesin boiler dengan nomor IDD000008936 atas nama Tergugat PT Basuki Pratama. ${ }^{49}$

Menurut Penggugat, bentuk tersebut tidak memiliki unsur kebaruan (not novel) karena desain mesin boiler Tergugat telah menjadi milik umum. Mesin boiler tipe tersebut sudah bukan merupakan desain yang dapat dikatakan baru karena sudah diproduksi secara masal oleh beberapa perusahaan mesin-mesin industri di Indonesia. 50

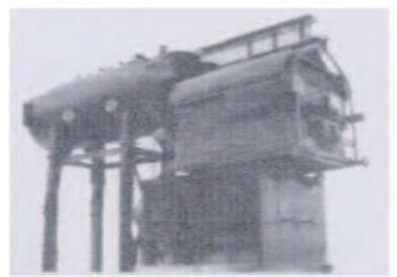

Bentuk di lindungi Desain Industri ${ }^{51}$

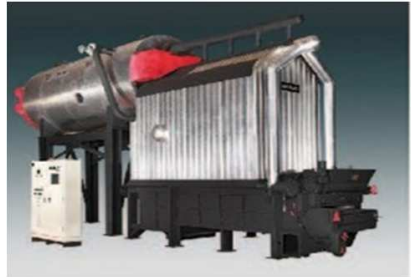

Bentuk yang digunakan oleh umum ${ }^{52}$

Putusan Mahakamah Agung ini berakhir dengan ditolaknya upaya hukum kasasi Penggugat, sehingga mesin boiler milik Tergugat dianggap memiliki kebaruan. ${ }^{53}$ Dalam kasus ini, Pengadilan menafsirkan bahwa suatu desain industri tersebut dianggap baru (novel) apabila desain tersebut memiliki perbedaan dari desain yang telah ada, meskipun perbedaan tersebut hanya sedikit dan pada bagian-bagian tertentu saja, sehingga masih menimbulkan kesan mirip dari desain yang telah ada sebelumnya.

Kedua perkara tersebut di atas merupakan dua perkara yang memiliki latar belakang permasalahan hukum yang serupa, akan tetapi diputuskan dengan menggunakan pertimbangan yang bertentangan mengenai syarat kebaruan. Dimana putusan pertama memberikan pertimbangan adanya perbedaan sedikit

49 Direktorat Jenderal Kekayaan Intelektual, Pangkalan Data Kekayaan Intelektual Desain Indsutri, Mesin Boiler, https://pdki-indonesia.dgip.go.id/index.php/di/ UXRWb3A2QWhxSElpdXdPM0JQTENndz09?q= mesin+boiler\&type=1 di kunjungi pada 18 Mei 2018.

${ }^{50}$ Putusan Mahkamah Agung pada tingkat kasasi No.19 K/N/HaKI/2006 Bukti P-13 a sampai dengan P$13 \mathrm{f}$ yang menunjukkan fakta jika desain industri boiler milik Basuki telah menjadi milik umum karena sudah banyak dipergunakan oleh perusahaan- perusahaan lain. Serta didukung Bukti P-14 a sampai dengan P-14 c, yang menunjukkan pengungkapan sebelumnya dari mesin boiler milik Basuki di dalam yellow pages edisi tahun 2002/2003; 2003/2004; dan 2004/2005 h.12. Boiler, Ibid.

${ }^{51}$ Direktorat Jenderal Kekayaan Intelektual, Pangkalan Data Kekayaan Intelektual Desain Indsutri, Mesin

${ }^{2}$ Putusan Mahkamah Agung pada tingkat kasasi No.19 K/N/HaKI/2006 Bukti P-13 a gambar yang menunjukkan fakta jika desain industri boiler milik Basuki telah menjadi milik umum karena sudah banyak dipergunakan oleh perusahaan- perusahaan lain.

${ }^{53}$ Ibid. 
antara suatu desain dengan desain yang telah ada, maka desain tersebut dapat dianggap memiliki kebaruan. Sedangkan putusan lainnya berpendapat sebaliknya, dimana suatu desain baru akan dikategorikan memiliki kebaruan jika memiliki perbedaan yang signifikan dengan desain lain yang telah ada sebelumnya.

\section{Tumpang-Tindih Antara Merek Tiga Dimensi dan Desain Industri}

Bagian ini akan menunjukkan persinggungan antara merek dan desain industri terkait dengan bentuk tiga dimensi. Sebelum dijelaskan lebih lanjut mengenai persinggungan tersebut, perlu dipahami ada juga bagian yang tidak bersinggungan. Bagian yang tidak bersinggungan ini memiliki peranan penting karena hal ini yang seharusnya menjadi dasar perbedaan konsep perlindungan antara merek dan desain indsutri. Bila konsep ini dipahami dan diatur dengan jelas baik secara eksplisit maupun implisit, maka tidak akan menciptakan kekeliruan hak perlindungan.

Pemberian perlindungan konsep merek dan desain indsutri sejatinya berbeda. Merek memberikan perlindungan dengan tujuan bahwa bentuk yang diberikan perlindungan tersebut mampu dibedakan dari produk serupa dan menunjukkan asal barang yang berkaitan dengan kualitas produk itu. ${ }^{54}$ Kadangkala, yang membuat harga suatu produk menjadi mahal bukan produknya, tetapi mereknya. ${ }^{55}$ Untuk menjadikan suatu merek menjadi terkenal yang mampu mewujudkan jaminan kualitas atau reputasi suatu produk tertentu tidaklah mudah, diperlukan waktu yang tidak sebentar serta biaya yang cukup tinggi. ${ }^{56} \mathrm{Hal}$ ini yang dilindungi dengan hak merek karena tidak menutup kemungkinan suatu merek terkenal akan ditiru oleh pihak yang beritikad tidak baik guna membonceng reputasinya. ${ }^{57}$ Dalam pembangunan reputasi tersebut di perlukan waktu yang tidak sebentar, maka dalam konsepnya, merek dapat diberikan perlindungan hak merek tanpa harus memenuhi unsur kebaruan seperti dalam desain industri selama merek tersebut memiliki perbedaan terhadap produk lain. Sementara itu,

${ }^{54}$ Haedah Faradz, Perlindungan Hak Atas Merek, Jurnal Dinamika Hukum Vol. 8 No. 1 Januari, Fakultas Hukum Universitas Jenderal Soedirman, Surabaya, 2008, hlm. 40.

55 OK Saidin, Ibid., hlm. 329.

${ }^{56}$ Haedah Faradz, Ibid. hlm. 97.

${ }^{57}$ Insan BudinMaulana, Sukses Bisnis Melalui Merek, Paten dan Hak. Cipta, Citra Aditya Bakti, Bandung, 1997, 
dalam desain industri bertujuan untuk melindungi suatu desain baru yang dihasilkan melalui proses pemikiran yang mana hasil itu bisa dilihat dalam kesan estetis yang ditampilkan oleh bentuk tersebut. ${ }^{58}$ Dengan kata lain, perlindungan desain industri diberikan sebagai bentuk penghargaan terhadap para desainer atas temuannya yang baru tersebut. ${ }^{59}$

Perbedaan mendasar antara merek dan desain industri adalah pada tujuan perlindungan dan unsurnya. Merek bertujuan membangun dan melindungi reputasi produk berkaitan dengan jaminan kualitasnya, sedangkan desain industri melindungi produk yang baru sebagai penghargaan terhadap penemuan yang baru tersebut. Selan itu, suatu merek harus memiliki daya pembeda yang mampu menunjukkan asalnya, sedangkan suatu desain industri harus baru dan memiliki kesan estetis.

Merek dan desain industri dalam pemberian perlindungannya, memiliki jangka waktu yang berbeda. Dalam Pasal 35 UU Merek, memberikan perlindungan selama jangka waktu 10 tahun sejak tanggal penerimaan dan jangka waktu tersebut dapat diperpanjang. Di dalamnya tidak disebutkan berapa kali jangka waktu perlindungan tersebut dapat diperpanjang, sehingga dapat ditafsirkan perlindungan merek ini dapat diperpanjang selamanya dengan sistem pendaftaran ulang setiap 10 tahun. Perlindungan ini dapat diperpanjang dengan catatan bahwa merek tersebut harus tetap ada dalam dunia perdagangan.

Berdasarkan Pasal 5 ayat (1) UU Desain Industri, perlindungan terhadap hak atas desain industri diberikan selama kurun waktu 10 tahun terhitung sejak tanggal penerimaan pendaftaran yang dimuat dalam daftar umum desain industri dan diumumkan dalam berita resmi desain industri Departemen Kehakiman Republik Indonesia. Dalam hal ini, tidak ada pengaturan mengenai perpanjangan perlindungan desain industri. Maka dari itu, sebuah desain industri yang lebih dari 10 tahun sudah tidak memiliki perlindungannya lagi, sehingga siapapun dapat menggunakan desain industrinya tersebut tanpa memerlukan izin dari pemilik desainnya. Hak desain industri tidak akan diberikan untuk desain industri yang

\footnotetext{
58 OK Saidin, Ibid., hlm. 470.

${ }^{59}$ Ranti Fauza Mayana, Perlindungan Desain Indsutri dalam Era Perdagangan Bebas, PT Gramedia Widiarsama, Jakarta, 2004, hlm. 90.
} 
telah kadaluwarsa untuk didaftarkan kembali oleh pemilik desain sebelumnya atau orang lain. ${ }^{60}$

Perlindungan terhadap desain industri dinyatakan dalam keterangan pemerintah bahwa waktu 10 tahun ini dianggap cukup memadai. Hal itu mengingat perkembangan di bidang industri mengalami perubahan yang cepat sesuai dengan tuntutan masa. Selain itu, dengan dibatasinya jangka waktu perlindungan tersebut juga untuk merangsang aktivitas kreatif dari para desainer untuk menciptakan desain yang baru. ${ }^{61}$ Jika melewati batas waktu yang ditentukan, maka desain industri yang bersangkutan dipandang sudah menjadi "kolot" atau old fashioned atau out of date. Desain industri tidak dapat lagi dianggap memenuhi kriteria estetika keindahan yang menjadi salah satu syarat adanya desain industri. ${ }^{62}$

UU Merek di dalam pengaturannya menyatakan bahwa bentuk tiga dimensi dapat dilindungi dengan hak merek. Hal yang perlu diperhatikan bahwa pada awalnya bentuk tiga dimensi dilindungi dengan desain industri. Munculnya UU Merek lantas menyebabkan pengaturan bentuk tiga dimensi terjadi dualisme, yaitu UU Merek dan UU desain Industri. Walaupun merek dan desain industri memiliki konsep yang berbeda, namun pengaturan di Indonesia yang berkaitan dengan perlindungan bentuk tiga dimensi di dalam UU Merek dan UU Desain Industri tidak memuat batasan yang jelas dalam hal kualifikasi bentuk tiga dimensi seperti apa yang dapat dilindungi dengan masing-masing undang-undang tersebut. Merek dan desain industri menetapkan batasannya hanya dengan daya pembeda pada merek, kesan estetis, dan prinsip kebaruan dalam desain industri tanpa penjelasan lebih lanjut. Dengan tidak adanya penjelasan lebih lanjut mengenai batasan tersebut terkait bentuk tiga dimensi, menjadikan batasan tersebut menjadi tidak pasti dan bersifat subjektif. Dikatakan bersifat subjektif karena batasanbatasan tersebut dapat ditafsirkan secara berbeda-beda oleh setiap pihak, bahkan hakim sekalipun. Ketidakjelasan pembatasan inilah yang menjadi titik singgung antara perlindungan merek dan desain indsutri.

\footnotetext{
${ }^{60}$ Puteri Melati, Ibid.

${ }^{61}$ Bagus Satrio Lestanto, Ibid., hlm. 93.

62 Sudargo Gautama dan Rizwanto Winata, Hak Atas Kekayaan Intelektual (HAKI) Peraturan Baru Desain Industri, Citra Aditya Bakti, Bandung, 2004, hlm. 18.
} 
Sebelumnya, telah dijelaskan bahwa jangka waktu perlindungan menjadi salah satu perbedaan mendasar antara merek dan desain industri, namun hal ini juga menjadi suatu titik singgung dalam perlindungan merek dan desain industri. Dikatakan demikian karena perlindungan merek memberikan jangka waktu yang tak terbatas dibandingkan desain industri. Tidak menutup kemungkinan bahwa orang lebih menginginkan perlindungan merek tiga dimensi dibanding desain industri.

Persinggungan merek tiga dimensi dan desain industri telah menjadi kekhawatiran beberapa pihak, bahkan kekhawatiran ini termuat dalam perancangan UU Merek. Seperti yang dikemukan dalam naskah akademik UU Merek bahwa perlindungan merek tiga dimensi perlu dilakukan secara cermat agar tidak menimbulkan tumpang-tindih dengan perlindungan desain industri yang jangka waktu perlindungannya terbatas dan tidak bisa diperpanjang lagi, serta tidak menimbulkan monopoli yang berlebihan terhadap merek. ${ }^{63}$ Saat ini pengaturan bentuk tiga dimensi dalam UU Merek tidak menjawab permasalahan yang telah disebutkan sebelumnya. Oleh karenanya, artikel ini menawarkan penjelasan mengenai bagaimana seharusnya memahami bentuk tiga dimensi dalam merek dan desain industri.

\section{Preskripsi Mengenai Batasan Antara Merek Tiga Dimensi dan Desain Industri di Indonesia}

UU Merek maupun UU Desain Industri, tidak mengatur secara komprehensif mengenai bentuk tiga dimensi, sehingga menjadi kelemahan dalam perlindungan bentuk tiga dimensi dalam kedua UU a quo karena menimbulkan tumpang-tindih pengaturan. Tumpang-tindih tersebut terjadi akibat pengaturan UU Merek maupun UU Desain Industri yang hanya membatasi penilaian sebatas pada ruang lingkupnya. Dari sisi merek, konsep dasar daya pembeda yang hanya mengacu pada tidak ditemukan persamaan pada pokoknya menyebabkan bentuk tersebut berhasil di lindungi dengan merek tiga dimensi. Sedangkan dari sisi desain industri, penerapan kesan estetis terhadap bentuk yang didaftarkan tidaklah

63 Badan Pembinaan Hukum Nasional, Laporan Akbir Naskah Akademik Peraturan Perundang-Undangan Rancangan Undang-Undang Tentang Merek, Jakarta, 2008, hlm. 23. 
mutlak. Hal ini terlihat dari bentuk produk yang sederhana tersebut dilindungi dengan desain industri.

Berdasarkan kelemahan tersebut, maka diperlukan batasan antara merek tiga dimensi dan desain industri, yang dilihat dari beberapa aspek yaitu bentuk umum, bentuk yang tidak boleh di daftarkan, persepsi publik, kekhasan akibat penggunaan dan perluasan cakupan suatu tanda untuk dapat dijadikan merek. Berikut akan dijelaskan satu-persatu, pertama, bentuk umum. Yang dimaksud bentuk umum adalah bentuk tersebut telah menjadi milik umum, yaitu telah banyak digunakan di perdagangan barang dan/atau jasa. Penerapan hal ini untuk mencegah tindakan monopoli dari bentuk yang mana seharusnya tersedia bebas untuk umum. Sehingga pemahaman bentuk umum harus diterapkan dalam UU Merek maupun UU Desain Industri. Kedua, bentuk yang tidak boleh di daftarkan. Mengenai bentuk yang tidak boleh di daftarkan, pengaturan di Uni Eropa adalah acuan yang tepat yaitu: bentuk yang dihasilkan dari sifat barang itu sendiri; bentuk yang diperlukan untuk mendapatkan hasil teknis; bentuk yang memberikan nilai substansial pada barang. ${ }^{64}$ Pengecualian bentuk tiga dimensi dari perlindungan merek tiga dimensi tersebut bertujuan agar bentuk yang demikian di lindungi dengan desain industri saja. Mengingat jangka waktu perlindungan merek yang dapat diperpanjang terus-menerus, maka ketentuan ini bertujuan untuk menghindari terjadinya monopoli sehingga dapat menghambat persaingan usaha yang sehat. Atas alasan tersebut bentuk tersebut dapat didaftarkan dengan desain industri selama mampu menyertakan bukti bahwa bentuk tersebut masih dapat di kembangkan.

Ketiga, yaitu persepsi publik dalam menilai suatu bentuk tiga dimensi, pemahaman dari persepsi publik ini bertujuan agar bentuk tersebut mendapatkan perlindungan sesuai dengan tujuan sebenarnya. Maksudnya, apabila publik menilai suatu bentuk dari penampakan sekilasnya memiliki daya pembeda maka bentuk tersebut dapat di daftarkan sebagai merek. Namun bila publik memerlukan penilaian analitis atau komparatif untuk menemukan perbedaan bentuk tersebut dari bentuk yang ada maka bentuk tersebut lebih tepat di lindungi sebagai desain

${ }_{64}$ Article 7 (1) (b) (e) of European Union Trade Mark Regulation 2017/1001 Of The European Parliament And Of The Council (EUTMR). 
industri. Keempat, terkait dengan bentuk yang mendapatkan kekhasan akibat penggunan, ketentuan ini dimaksudkan agar suatu bentuk tiga dimensi yang baru didaftarkan dengan desain, setelah bentuk tersebut memperoleh kekhasaan akibat penggunaan maka desain tersebut dapat di daftarkan dengan merek tanpa mengesampingkan ketentuan bentuk yang tidak boleh di daftarkan. Kelima, adalah cakupan penolakan suatu tanda untuk dapat dijadikan merek, dimana dalam Pasal 21 (1) (a) UU Merek menyatakan bahwa Permohonan ditolak jika merek tersebut mempunyai persamaan pada pokoknya atau keseluruhannya dengan merek terdaftar milik pihak lain atau dimohonkan lebih dahulu oleh pihak lain untuk barang dan/atau jasa sejenis. Sehingga untuk memperluas cakupan penolakannya dapat dirumuskan sebagai berikut:

Permohonan ditolak jika bentuk tiga dimensi Merek tersebut mempunyai persamaan pada pokoknya atau keseluruhannya dengan bentuk tiga dimensi Hak Kekayaan Intelektual terdaftar milik pihak lain atau dimohonkan lebih dahulu oleh pihak lain untuk barang dan/atau jasa

Penambahan kata "bentuk tiga dimensi" dimaksudkan untuk menekankan pada fokus merek tiga dimensi. Pemilihan kata "hak kekayaan intelektual lain" dan bukan "desain industri" mengacu pada pemikiran bahwa bentuk tiga dimensi tersebut akan dibandingkan dengan bentuk tiga dimensi dalam lingkup perlindungan kekayaan intelektual yang lain.

\section{Penutup}

Berdasarkan analisis di atas, maka dapat disimpulkan, pertama, pemahaman yuridis konsep bentuk tiga dimensi dalam Undang-Undang No. 31 Tahun 2000 tentang Desain Industri adalah pada perlindungan terhadap bentuk tiga dimensi yang dapat digunakan untuk menghasilkan suatu produk, barang, komoditas industri, atau kerajinan tangan. Dalam konsep desain industri, pengaturan perlindungan hukumnya berdasarkan pada pola yang digunakan untuk membuat barang secara berulang-ulang.Dalam perkembangan perlindungan kekayaan intelektual Undang-Undang Merek No. 20 Tahun 2016 tentang Merek dan Indikasi Geografis menyatakan bahwa bentuk tiga dimensi menjadi salah satu objek perlindungannya. Obyek perlindungan pada merek yaitu apakah tanda suatu 
merek memiliki kesamaan secara pokok atau kesamaan secara keseluruhan dengan merek terkenal atau dengan yang lebih dulu terdaftar.

Kedua, persamaan objek perlindungan ini membawa konsekuensi pada terjadinya tumpang-tindih perlindungan bentuk tiga dimensi pada merek dan desain industri. Dalam pembahasan artikel ini, telah dipaparkan bahwa meskipun merek dan desain industri sama-sama melindungi bentuk tiga dimensi, namun objek perlindungannya berbeda. Hal ini disebabkan oleh dasar yang menjadi landasan perlindungan masing-masing rezim. Perbedaan mendasar antara merek dan desain industri adalah pada tujuan perlindungan dan unsurnya. Tujuan perlindungan merek adalah membangun dan melindungi reputasi produk terkait dengan jaminan kualitas, sedangkan desain industri bertujuan melindungi produk yang baru untuk menghargai penemuan baru tersebut. Dilihat dari unsurnya, daya pembeda antara keduanya yaitu desain industri menitikberatkan pada kebaruan dan kesan estetis sedangkan merek menitikberatkan pada asalnyas. Selain itu, dalam perlindungannya, merek memberikan jangka waktu yang tak terbatas dibandingkan desain industri. Tumpang tindih pengaturan tersebut akan menimbulkan persoalan kepastian hukum dalam mengatur bentuk tiga dimensi.

Ketiga, berdasarkan hal tersebut maka diperlukan batasan antara merek tiga dimensi dan desain industri, yang dilihat dari beberapa aspek yaitu bentuk umum, bentuk yang tidak boleh didaftarkan, persepsi publik, kekhasan akibat penggunaan dan perluasan cakupan suatu tanda untuk dapat dijadikan merek.

\section{Daftar Pustaka}

\section{Buku}

Black, T, Intellectual Property in Industry, Butterworths, London, 1989.

Badan Pembinaan Hukum Nasional, Naskah Akademik Rancangan Undang-Undang Tentang Desain Industri, Jakarta, 2013.

Ditjen HKI (Bekerja sama dengan EC-ASEAN IPRs Co-operation Programme (ECAP II), Buku Panduan Hak Kekayaan Intelektual Dilengkapi dengan Peraturan Perundang-Undangan Di Bidang Hak Kekayaan Intelektual, Jakarta, ditjen HKI-ECAP II, 2006.

Djumhamna, Muhammad, Aspek - Aspek Hukum Desain Industri di Indonesia, Citra Aditya Bakti, Bandung, 1999. 
Gautama, Sudargo, dan Rizwanto Winata, Hak Atas Kekayaan Intelektual (HAKI) Peraturan Baru Desain Industri, Citra Aditya Bakti, Bandung, 2004.

Kusmiati, Artini, Dimensi Estetika Pada Karya Arsitektur dan Desain, Djambatan, Jakarta, 2004.

Maulana, Insan Budi, Sukses Bisnis Melalui Merek, Paten dan Hak Cipta, Citra Aditya Bakti, Bandung, 1997.

Mayana, Ranti Fauza, Perlindungan Desain Indsutri dalam Era Perdagangan Bebas, PT Gramedia Widiarsama, Jakarta, 2004.

Purba, Affilyonna Gazalba Saleh dan Adriana Krisnawati, Konsep Hak Kekayaan Intelektual, Penerbit Rineka Cipta, Jakarta, 2005.

Purba, Achmad Zen Umar, Hak Kekayaan Intelectual Pasca TRIPs, Alumni, Bandung, 2005.

Purwaningsih, Endang Perkembangan Hukum Intellectual Property Rights, Ghalia Indonesia, Bogor, 2005.

Saidin, OK, Aspek Hukum Hak Kekayaan Intelektual, PT Raja Grafindo, Jakarta, 2013.

Santoso, Budi, Butir-Butir Berserakan tentang Hak Atas Kekayaan Intelektual (Industri), CV. Mandar Maju, Bandung, 2005.

Usman, Rachmadi, Hukum Hak atas Kekayaan Intelektual, Cetakan ke 1, edisi pertama, Penerbit Tim Alumni, Bandung, 2003.

Utomo, Tomy Suryo, Hak Kekayaan Intelektual (HKI) di Era Global, Graha Ilmu, Yogyakarta, 2010.

Wauran, Indirani Wicaksono, Pengantar Hukum Kekayaan Intelektual, Penerbit Tisara Grafika, Salatiga, 2017.

\section{Hasil Penelitian/Tugas Akhir}

Wahyu, Ana, Konsep Merek Tiga Dimensi dalam Hukum Merek Indonesia, Skripsi Fakultas Hukum Universitas Kristen Satya Wacana, Salatiga, 2018.

Lestanto, Bagus Satrio, Konsep Perlindungan Merek Tiga Dimensi: Definisi, Perlindungan dan Penerapan Hukum, Skripsi, Universitas Indonesia, Jakarta.

Jurnal

Adiyan, Agitya Kresna, "Penerapan Prinsip Kebaruan (Novelty) Dalam Perlindungan Desain Industri di Indonesia, (Studi Kasus Desain Industri Iphone 3G Apple Inc. v. Galaxy S Samsung Electronics Co.Ltd)," Jurnal Ilmiah, Fakultas Hukum Universitas Brawijaya, Malang, 2013.

Dewanti, Liona Isna, "Tolok Ukur Kebaruan Dalam Desain Industri," Ius Quia Iustum Law Journal of Islamic University of Indonesia JURNAL HUKUM UII NO. 1 VOL. 14 JANUARI 2007. 
Edelman, Sandra, et.al., "Annual Review: The Twelfth Annual International Review of Trademark Jurisprudence", Official Journal of The International Trademark Association, Volume 95, Nomor 2, 2005.

Faradz, Haedah, "Perlindungan Hak Atas Merek", Jurnal Dinamika Hukum Vol. 8 No. 1 Januari , Fakultas Hukum Universitas Jenderal Soedirman , Surabaya, 2008.

Mastur, "Perlindungan Hukum Hak Kekayaan Intelektual Dibidang Paten", Jurnal Ilmiah Ilmu Hukum QISTI Vol. 6 No. 1 Januari 2012.

Sufiarina, "Hak Prioritas Dan Hak Ekslusif Dalam Perlindungan HKI," Jurnal Hukum ADIL Vol. 3 No.2.

Putra, Fajar Nurcahya Dwi, "Perlindungan Hukum Bagi Pemegang Hak Atas Merek Terhadap Perbuatan Pelanggaran Merek", Jurnal Ilmu Hukum Edisi Januari - Juni 2014.

Susiana, Dewi, "Pembatalan Desain Industri Karena Alasan Mempunyai Persamaan Pada Pokoknya," PREMISE LAW JURNAL Vol 1 No 2, Medan, 2013.

Wauran, Indirani dan Titon S. Kurnia, "Confusion dan Pembatalan Merek oleh Pengadilan," Mimbar Hukum Vol.27, Yogyakarta, 2015.

\section{Peraturan Perundang-Undangan}

Undang-undang Republik Indonesia Nomor 20 Tahun 2016 tentang Merek dan Indikasi Geografis (Tambahan Lembaran Negara Republik Indonesia Nomor 5953).

Undang-undang Republik Indonesia Nomor 31 Tahun 2000 tentang Desain Industri (Tambahan Lembaran Negara Republik Indonesia Nomor 4045).

\section{Putusan Pengadilan}

Putusan Mahkamah Agung Nomor : 022 K/N/HaKI/2006

Putusan Mahkamah Agung perkara Nomor : 022 K/N/HaKI/2006

Putusan Mahkamah Agung No.19 K/N/HaKI/2006

\section{Internet}

Direktorat Jenderal Kekayaan Intelektual, Pangkalan Data Kekayaan IntelektualMerek, https://pdkiindonesia.dgip.go.id/index.php/merek/ VW11RHdSdk95UmdYbk8zeERKREZyZz09?q= tiga+dimensi\&type= $1 \&$ skip $=10 \&$ sort_by $=\&$ sort_type $=$ desc, di kunjungi pada 17 Mei 2018 pukul 23.04.

https://www.google.com/search?q=kemasan, di kunjungi pada 17 Mei 2018 pukul 23.18.

Kamus Besar Bahasa Indonesia, https://kbbi.web.id/estetis, di kunjungi pada 10 Mei 18 pukul 16.05. 
Direktorat Jenderal Kekayaan Intelektual, Pangkalan Data Kekayaan Intelektual Desain Indsutri , Gambar pertama “BROS BENTUK KUPU-KUPU” dengan nomor pendaftaran IDD000032807 dan gambar kedua "BOTOL DENGAN BENTUK KATAK" dengan nomor pendaftaran IDD000039919 yang terdaftar dibawah perlindungan desain industri, https://pdkiindonesia.dgip.go.id/index.php/di?q=bentuk

\&type=1\&filter_by=didaftar di kunjungi pada 18 Mei 2018.

Direktorat Jenderal Kekayaan Intelektual, Pangkalan Data Kekayaan Intelektual Desain Indsutri, plastik pembungkus CD, VCD dan DVD https://pdkiindonesia.dgip.go.id/index.php/di/Vml0WS93dFM0RIRDVFFBajVqRTBuQT09? q=ID+0002596\&type=1 di kunjungi pada 18 Mei 2018 pukul 13.23.

Direktorat Jenderal Kekayaan Intelektual, Pangkalan Data Kekayaan Intelektual Desain Indsutri, Mesin Boiler, https://pdki-indonesia.dgip.go.id/ index.php/di/ UXRWb3A2QWhxSElpdXdPM0JQTENndz09?q=mesin+ boiler\&type=1 di kunjungi pada 18 Mei 2018 pukul 14.38 . 